University of Pennsylvania Carey Law School

Penn Law: Legal Scholarship Repository

Faculty Scholarship at Penn Law

1992

\title{
Bargaining and the Division of Value in Corporate Reorganization
}

\author{
Howard F. Chang \\ University of Pennsylvania Carey Law School
}

Lucian A. Bebchuk

Follow this and additional works at: https://scholarship.law.upenn.edu/faculty_scholarship

Part of the Bankruptcy Law Commons, Business Law, Public Responsibility, and Ethics Commons, Business Organizations Law Commons, Corporate Finance Commons, Dispute Resolution and Arbitration Commons, Economic Policy Commons, Economics Commons, Law and Economics Commons, and the Work, Economy and Organizations Commons

\section{Repository Citation}

Chang, Howard F. and Bebchuk, Lucian A., "Bargaining and the Division of Value in Corporate Reorganization" (1992). Faculty Scholarship at Penn Law. 971.

https://scholarship.law.upenn.edu/faculty_scholarship/971

This Article is brought to you for free and open access by Penn Law: Legal Scholarship Repository. It has been accepted for inclusion in Faculty Scholarship at Penn Law by an authorized administrator of Penn Law: Legal Scholarship Repository. For more information, please contact PennlawIR@law.upenn.edu. 


\title{
Bargaining and the Division of Value in Corporate Reorganization
}

\author{
Lucian Ayre Bebchuk \\ Harvard Law School and the National Bureau of Economic Research \\ Howard F. Chang \\ Massachusetts Institute of Technology
}

\section{Introduction}

Reorganization is one of the two alternatives open to an insolvent corporation under the Bankruptcy Code. A bankrupt corporation may file either for liquidation under Chapter 7 or for reorganization under Chapter 11 of the Bankruptcy Code. Upon a filing for liquidation, a court immediately appoints a trustee to sell the firm's assets, either piecemeal or as a going concern, to outside buyers. The proceeds from this sale are divided among those who have rights against the corporation, with the division made according to the ranking of these rights by legal priority.

The firm may go instead into Chapter 11, under which the firm can be "reorganized." In reorganization there is no sale to third parties. Rather, there is a "hypothetical sale" of the firm to the existing "participants" — all those who hold claims or rights against the insolvent company. These participants surrender their claims and rights in exchange for claims and rights against the new corporation. For example, a bankrupt company may emerge from reorganization with all its debt canceled and with the former debtholders holding some or all of the equity of the reorganized company.

We wish to thank Oliver Hart, Marcel Kahan, Kevin Kaiser, Louis Kaplow, Roberta Romano, Steve Shavell, Jeff Zwiebel, two anonymous referees, and participants in workshops at Harvard and M.I.T. for helpful comments and the John M. Olin Foundation for financial support. Lucian Bebchuk's work has been supported also by the National Science Foundation. 
If the court supervising a reorganization could observe the value of the reorganized firm, it would allocate that value among the participants according to the legal priority of their claims. For example, consider a company that has equityholders and that owes debtholders $\$ 200$, and suppose that the court observes that the value of the reorganized company will be $\$ 150$; in this case, the court would order that all of the reorganized company's securities be given to the debtholders, and none be given to the equityholders. Below we will use the term "contractual right" to mean that which a class would receive if the bankruptcy court could observe the firm's value and distributed it among the classes according to the initial contracts, that is, strictly in the order of the legal priority of their claims.

Because a court cannot determine accurately an objective figure for this value, however, the law leaves the division of the reorganized company's value to a process of bargaining among the classes of participants. Under the Bankruptcy Code, each class of equityholders and debtholders whose interests are impaired must vote to approve a reorganization plan, which would include a division of value. The approval by a class requires a certain majority of the class members to vote in favor of the plan. As is generally believed by participants in reorganization and as will be shown in this article, the outcome of this bargaining process often diverges from the contractual rights of the classes.

In Section 2 of this article, we develop a sequential bargaining model of the negotiations in corporate reorganizations under Chapter 11 . We identify the expected outcome of the bargaining process and examine the effects of the legal rules that shape the bargaining. We determine how much value each class will receive and what factors give each class an advantage or a disadvantage in the bargaining process. We also compare the share of the reorganized firm's value that each class obtains under the existing legal regime with the contractual right of that class. ${ }^{1}$

The critical features of the situation that we model are as follows. Oncc an insolvent company files for reorganization under Chapter 11, an "automatic stay" prevents debtholders from seizing the company's assets as long as the company is in Chapter 11. If there is no agreement on a reorganization plan, eventually the supervising court would convert the bankruptcy proceedings to a Chapter 7 sale. For the debtholders to obtain any value before such a

1. In spite of the growing interest by cconomists in corporate reorganization, little work has been done thus far to model bargaining under Chapter 11. Brown analyzed this bargaining, but his model does not include certain important features of the process that we seek to incorporate. First, whereas time plays no role in Brown's model, we analyze the implications of the critical fact that upon filing for Chapter 11 a company may be kept in Chapter 11, protected from creditors, for some time. As our model shows, the bargaining is shaped by the possibility of such a delay, because the value available for division may well change over time as a result of the realization of uncertainty and the company's incurring financial distress costs. Moreover, whereas in Brown's model no class can make many offers, we develop a sequential bargaining model in which each class can make many offers during the Chapter 11 period.

In surveying past work, note should be made of the related literature about debt renegotiation 
conversion, however, the two classes, equityholders and debtholders, must agree on a division of value (i.e., on a reorganization plan).

If the parties do not agree immediately, and the company remains in Chapter 11 for some time, then the value available for division may well change, for two reasons. First, the company would incur some "financial distress costs," to be discussed later, which would reduce its value. Second, uncertainty will be realized: random shocks may increase or decrease the firm's value. Furthermore, if the two classes ultimately do not reach agreement, and the assets are sold under Chapter 7, such a sale might sometimes involve a loss of value. These potential consequences of the parties' failure to reach agreement are important elements of our model, because they provide the background against which the parties would decide which offers to make or accept.

Empirical studies of corporate reorganization (e.g., Eberhart, Moore, and Roenfeldt; Weiss; Franks and Torous) confirm that Chapter 11 often enables equityholders to obtain a share of the value of the reorganized company even when that value is less than sufficient to cover debtholders' claims. The debtholders often agree to plans giving the equityholders a share of this value even when the debtholders are not paid in full. Our model identifies and analyzes three sources of the equityholders' ability to obtain value and the parameters that determine how much value they will obtain.

As will be shown, Chapter 11 gives equityholders the ability to obtain value, even though the company is insolvent. The fact that their consent is necessary for a division of value enables equityholders to obtain value for three reasons. The first two reasons arise from the ability of the equityholders to delay the adoption of a reorganization plan from the beginning of the Chapter 11 period to a later date. First, if equityholders delay agreement, there may be a favorable resolution of uncertainty that would cause the value of the firm to exceed the value of its debt. Thus, the equityholders have an "option value," and to forgo it they must be compensated by the agreed distribution of value. Second, if the equityholders withhold their consent and thereby delay agreement, the company will be expected to incur "financial distress costs" that will erode the value that debtholders can expect to receive. Thus, the equityholders' consent to a division of value can save the firm "financial distress costs," and therefore they can obtain a share of these

(see, e.g., Bergman and Callen; Hart and Moore, 1989; Giammarino; and Webb). (Of these articles, the closest to ours in modeling approach is that of Bergman and Callen, who also use a sequential bargaining model, though not one in which the firm value may fluctuate during the bargaining period as a result of the realization of uncertainty.) Debt renegotiation prior to formal bankruptcy proceedings, however, differs from that within such proceedings. Our focus, of course, is on bargaining within Chapter 11 with special emphasis on how the legal rules of Chapter 11 shape this process.

Finally, after developing our model, we learned about an independent effort to develop a sequential bargaining model of Chapter 11 by Baird and Picker. While they share our approach, their model differs substantially from ours; in particular, in their model the company's value is assumed not to change during the Chapter 11 period. 
savings. The fraction of these savings that they obtain depends upon the rules that govern the Chapter 11 bargaining. In particular, the equityholders in effect have an exclusive power to propose reorganization plans for a period of time, which increases the fraction of the savings of "financial distress costs" that the equityholders can capture.

The third reason that the equityholders can obtain value (even when the value of the reorganized firm is insufficient to pay the debt in full) arises when the parties expect a Chapter 7 sale to entail a loss of value. In this case, the equityholders' consent to a division of value is necessary to avoid this loss. Therefore, they can obtain a fraction of the value gained by avoiding a Chapter 7 sale.

The model in Section 2 reveals how much each of the elements descriped above contributes to the value that equityholders will receive. Comparative statics analysis is also presented in Section 2. In particular, the amount that equityholders will receive tends to increase with (i) the volatility of the value of the company's assets, (ii) the extent to which reorganization imposes "financial distress costs," (iii) the length of the reorganization period, (iv) the length of the period during which the equityholders have the exclusive right to make offers, ( $v$ ) the extent to which liquidation imposes a loss in value, and (vi) the extent to which the value of the company's assets covers the company's debts. As will be discussed, these results provide several testable implications of the model.

Finally, concluding remarks on some issues for further research are offered in Section 3. While we focus on the positive analysis of the bargaining process under Chapter 11, this analysis is a prerequisite for a normative analysis of the efficiency costs of Chapter 11. Accordingly, in Section 3, we discuss the implications of the model for the welfare effects of Chapter 11 .

\section{The Model}

2.1 Framework of Analysis

We consider a company with one class of equity and one class of debt that files for bankruptcy under Chapter 11. Let $V$ be the value of the company's assets at the time of filing. ${ }^{2}$ Upon filing for bankruptcy, the company owes an amount $D$, where $D>V$. Thus, the value of the assets is insufficient to cover the debt in full. (In Section 2.7, we discuss how the model can be extended to the case in which $D \leq V$.)

The firm is to emerge from the reorganization with an all-equity structure or some other capital structure that avoids the "financial distress costs" to be described below. Under Chapter 11, the corporate reorganization process ends when the various classes of investors accept a plan including a division of value. If the parties fail to agree on a reorganization plan, the supervising court would eventually convert the bankruptcy proceedings to a Chapter 7 liquidation (usually following a petition by creditors). For concreteness, we

2. More specifically, $V$ is the value that the company would have if its capital structure were such that the firm is not expected to incur the "financial distress costs" to be described below. 
assume that if the parties fail to reach an agreement within a time period $T$, the company will be liquidated. The firm remains in Chapter 11 reorganization until time $t=T$ unless the parties reach agreement before then. ${ }^{3}$

For an agreement on the distribution of value, one class must propose a reorganization plan, and then both classes must accept it. The Bankruptcy Code and the Bankruptcy Rules, however, include certain notice and hearing requirements that introduce a delay of at least 25 days between offer and response. ${ }^{4}$ In this respect, bargaining in the reorganization context differs from that in other contexts, in which each round of bargaining - an offer and the response to it-can take a very short period of time.

Let $\Delta t$ be the length of one round of bargaining, that is, the time required until a proposed reorganization plan can be accepted or rejected under Chapter 11. Let $n=T / \Delta t$ (assumed for simplicity to be an integer greater than 1 ) be the number of bargaining rounds during the reorganization period. Let $V_{i}$ denote the value of the company if the parties adopt a reorganization plan at the end of round $i$, where $i=1, \ldots, n .^{5}$

The firm's value $V_{i}$ evolves over time. That is, if the parties approve a reorganization plan in any round after round 1 , the value divided might differ from $V_{1}$. Specifically, if delay were to occur, the value may change for the following two reasons. One reason is that the firm will bear "financial distress costs"-efficiency costs that the firm must incur while it is in Chapter 11 and that it would not incur if it had a new capital structure. There are several sources of financial distress costs. First, Chapter 11 bankruptcy involves significant administrative costs; indeed, the fees paid to lawyers, accountants, various professional consultants, and expert witnesses in a Chapter 11 reorganization of a publicly traded company are often on the order of tens of

3. Our assumption that the firm cannot emerge from Chapter 11 before $t=T$ without an agreement is a simplification of the legal rules. In reality, the equityholders can impose a plan on the debtholders so long as the debtholders are paid in full. The equityholders would choose to exit Chapter 11 by paying $D$ in full if during the bargaining the value of the firm were to rise sufficiently above $D$, for much the same reasons (to be discussed below in Section 2.7) that they would rather avoid Chapter 11 if $V$ were sufficiently greater than $D$.

We adopt our simplifying assumption for convenience; a more complex model could include this option for the equityholders to exit Chapter 11 but would not yield results significantly different from ours. In particular, this extension of our model would not change the direction of our comparative statics results. The addition of such an "exit option" would only increase the share of the firm obtained by the equityholders. This option can only strengthen the equityholders' bargaining power, because they would exercise this option only if it would improve their payoffs.

4. In particular, after the filing of a Chapter 11 case, acceptance for any particular plan may not be solicited until after a hearing by the supervising court held on 25-days notice to the parties in interest.

5. Once the firm is reorganized and its shares are distributed, its new shareholders would obviously have the power to select the company's management. We do not analyze the possibility that either the equityholders or the debtholders have any special management skills necessary for running the company. Ignoring this possibility appears quite appropriate for publicly traded firms, which are often run by professional managers. Baird and Picker, who focus on the reorganization of closely held firms with a small group of shareholders-managers, consider the interesting implications of the presence of shareholders-managers with some special management skills. 
millions of dollars. In one recent reorganization of a major corporation, the bankruptcy expenses of the company and of the creditor committees came to $\$ 3.5$ million per month (see Cutler and Summers:167). Second, potential business partners may be reluctant to deal with the company or may demand especially favorable terms, for those doing business with a firm in financial distress may incur greater information costs, monitoring costs, enforcement costs, and collection costs. Third, financial distress might lead to inefficient management decisions, especially with respect to the choice of projects and investments (see, e.g., Jensen and Meckling; Myers; Hart and Moore, 1990). For an empirical investigation of such financial distress costs, see Lang and Stulz. We assume that as a result of these financial distress costs, the company loses an amount of its value continuously over time at the rate of $\alpha$ per period $\Delta t$ - that is, per round of bargaining - as long as the company is in Chapter $11 .^{6}$

The second reason for $V_{i}$ to change over time is that uncertainty will be realized. Random shocks may increase or decrease the value of the company's assets. We assume that during each round of bargaining, unpredictable events would cause this value to be either higher or lower than expected by the amount $\theta$, and that either state of the world occurs with equal probability. The parameter $\theta$, then, represents the volatility of the firm's value. For concreteness, we assume that at the beginning of each round, information is revealed that causes the value of the firm to either rise or fall instantaneously by the amount $\theta$.

Let the value realized after revelation of information at the start of round 1 be $V$ and let $V_{i}$ be the value at the end of round $i$. Thus, $V_{1}=V-\alpha$, and $V_{i}=$ $V_{i-1}+\delta_{i}$, for $i=2, \ldots, n$, where $\delta_{i}=-\alpha-\theta$ with probability $\frac{1}{2}$, and $\delta_{i}=$ $-\alpha+\theta$ with probability $\frac{1}{2}$. The value of $\delta_{i}$ is realized at the start of round $i$, before the $i$ th offer is made. We assume $0<\alpha<\theta$, so that the company's value will increase with probability $\frac{1}{2}$ despite the financial distress costs. We also assume that $(n-1)(\alpha+\theta)<V_{1}$, so that the company's value cannot disappear completely during the reorganization period. ${ }^{7}$

6. Note that the financial distress costs in our model result from the firm's mere presence in Chapter 11 and would be eliminated only if a reorganization agreement were reached (creating a sound financial structure). We abstract from the possibility that the shareholders might be able to cause some deterioration beyond the one resulting from the firm's being in Chapter 11 and, seeking to get concessions from the debtholders, might threaten to do so. Bergman and Callen present an interesting model of threats by shareholders of solvent firms to deliberately cause some deterioration in the situation of the firm. As they discuss, a critical question with respect to such threats is that of credibility. The credibility issue does not arise with respect to the financial distress costs in our model, because these costs would be incurred, whether or not the shareholders wish to have them, as long as the firm is in Chapter 11 .

7. For simplicity, we can assume that the interest rate is zero, so that there is no discounting. Alternatively, we can allow for a positive interest rate and interpret all variables representing values-such as $V, V_{1}$, and $D$-as present discounted values. Under this interpretation, we would assume that all equityholders and debtholders share a common discount rate, which would also equal the interest rate on the debt. $V$ would denote the present discounted value of the future stream of earnings that the assets would produce if the firm were reorganized at time $t=0$. Similarly, $V_{i}$ would be the corresponding value (discounted to time $t=0$ ) if the firm were reorganized at the end of round $i$. 
We also assume the following timing of events. In each round, once the uncertainty is realized, one party proposes a reorganization plan, that is, a division of the value that will exist at the end of the round. At the end of the round, after the delay created by the rules governing the solicitation of acceptances, the value has deteriorated by the amount $\alpha$. At this point, the two classes decide whether to accept or reject the plan. The class proposing the plan, naturally, votes to accept the proposal. If the other class also accepts the proposal, the plan is confirmed, and the firm immediately emerges from Chapter 11 with its value divided according to the plan. If the other class instead rejects the proposal, then the parties go to the next round of bargaining. ${ }^{8}$

As in any sequential bargaining model, it is necessary to specify a procedure that determines which party makes the offer in each round. In the case of Chapter 11 bargaining, the Bankruptcy Code determines some of this bargaining protocol. The Bankruptcy Code establishes a period during which only the debtor (i.e., the incumbent management) has the right to propose reorganization plans. The incumbent management generally will have at least six months in which to produce a reorganization plan and obtain the necessary acceptances, and courts may grant extensions of this period (see Trost:1325). Although the insolvent corporation and its management have fiduciary duties to creditors as well as shareholders, most observers expect management to favor the interests of shareholders. As Normandin (1989:56-8) notes, management not only is elected by the shareholders but also often holds a substantial interest in the corporation's stock. Consistent with this observation, this article assumes that with respect to proposals to divide the value of the reorganized firm between equityholders and debtholders, management acts on behalf of the equityholders. ${ }^{9}$

To represent the period during which the management has the exclusive

8. The above description of the sequence of events assumes implicitly that each class of claimants acts as a single agent. We assume that the set of equityholders and the set of debtholders are mutually exclusive. Given our assumptions, there is no conflict of interest among the class members, and they will all agree on whether a plan should be accepted or rejected.

Given the homogeneity of each class in the model, there is no need to introduce the possibility that exists under section 1129 (a) (7) of the Bankruptcy Code for a veto by an individual member. Under that provision, dissenting members can veto a plan that fails the "best interests of the creditors" test-that is, a plan that provides them with less than the liquidation value of their claims - even if the required majority of the class votes to accept the plan. When there are differences in preferences or in information among class members, then individual members may wish sometimes to exercise such a veto. But if there are no such differences among class members, as we assume, then no member would wish to veto a plan that other members of the class voted to approve.

9. It is not our assumption that management acts in the equityholders' interests in all respects. The interests of the equityholders and of management may well diverge with respect to certain investment decisions. With respect to management's proposals to divide the value of the reorganized firm between equityholders and debtholders, however, we believe it reasonable to assume that management will prefer the interests of equityholders.

The assumptions that the managers initially have exclusive control of the bargaining agenda, and that they use this control to the advantage of the equityholders, do not matter much for our results. As will be noted, one can easily modify our model to accommodate the case in which 
right to propose plans, we assume that the equityholders make at least the first offer and possibly the first several offers. That is, they have the exclusive right to make offers for the first $e$ rounds, where $e$ is an integer such that $0<e<n$. Over the remaining $n-e$ rounds, both classes may make offers. (This possibility is indeed contemplated by Chapter 11, and firms often remain in Chapter 11 even after the exclusive period runs out.) To capture the possibility of either party making the offer in any given round, we assume that at the beginning of each of these $n-e$ rounds, the identity of the class making the offer is determined randomly, with the probability of each equal to $\frac{1}{2} \cdot{ }^{10}$

If the parties were to fail to reach agreement in round $n$, we assume that the court would convert the proceedings to a Chapter 7 liquidation. In that event, the assets of the company would be sold. Let the random variable $L$ denote the value obtained through such a sale, which would then be divided according to the legal priority of the parties' claims. That is, equityholders get an amount $V E_{L}=\max (0, L-D)$, and debtholders get the complementary share, $V D_{L}=$ $L-\max (0, L-D)=\min (L, D)$. At this point, we will assume that $L=V_{n}$; that is, we assume that the sale procedure occurs immediately and does not involve any loss of value. In Section 2.5, however, we will drop the assumption that $L=V_{n}$ and extend the analysis to cover the case in which $L<V_{n}$.

We also assume that all parties are risk neutral. Thus, each class seeks to maximize the expected value of its share. Finally, we assume that the structure of the bargaining game described above-including the values of the parameters $V_{1}, D, L, \alpha, \theta, T, e$, and $n-$ is common knowledge to the participants.

\subsection{The Division of Value}

Under the assumption of common knowledge, the parties will reach an agreement at the end of round 1 . As in the sequential bargaining game analyzed by Rubinstein, to obtain agreement, the party making the proposal in round $i$ would offer the other at least what the other could obtain in expected value in round $i+1$, where $i=1, \ldots, n-1$. Each party would offer just this amount to the other in order to maximize its own share. It cannot expect to do better by asking for any larger amount, which would delay agreement and allow the other party to make the next offer.

The party whose turn it would be in round $i$, denoted by $X$, offers to take the amount $V X_{i}$ of the total value $V_{i}$. By the argument above,

$V X_{i}=V_{i}-E_{i}\left[V_{i+1}-V X_{i+1}\right]$,

there is no initial agenda control or the case in which the control is not exercised in the interest of equityholders, and these modifications do not have important effects on our conclusions. See Section 2.8 and note 14 , respectively.

10. Having each party make the offer with probability $\frac{1}{2}$ in each round is one of the two conventional alternatives in modeling a situation in which two parties can make offers. The second alternative is to assume that the two parties alternate in making offers. In a model with a finite number of rounds (such as ours), however, the first alternative ensures that the division of value is not sensitive to whether the number of rounds, $n$, is even or odd. We prefer the first method because it renders it unnecessary to make such arbitrary assumptions regarding $n$. 
where $V X_{i+1}$ denotes the amount $X$ would obtain under the plan proposed in the next round, and $E_{i}$ denotes the expected value conditional on information available in round $i$, that is, conditional on the realized value of $V_{i}$. By our assumptions about $\delta$, we also know that the expected "efficiency gain" from an agreement in round $i$ rather than round $i+1$ is

$V_{i}-E_{i}\left[V_{i+1}\right]=-E_{i}\left[\delta_{i+1}\right]=\alpha$.

Using (2) to substitute into (1),

$V X_{i}=\alpha+E_{i}\left[V X_{i+1}\right]$

Thus, when the party making the offer, $X$, holds the other to its expected payoff next round, $X$ thereby takes for itself the expected "efficiency gain," $\alpha$, plus its own expected payoff next round.

Under liquidation at the end of round $n$, equityholders would receive $V E_{L}$, and debtholders would receive $V D_{L}$, where $V E_{L}+V D_{L}=L=V_{n}$. In round $n$, the party making the offer cannot gain by proposing any other division, because the other party will reject any proposal offering it a smaller share. Therefore, $V E_{n}=V E_{L}$ and $V D_{n}=V D_{L}$. The party making the $n$th offer cannot capture any "efficiency gain" from avoiding financial distress costs, because we have assumed here that liquidation occurs costlessly and immediately upon rejection of the offer.

We solve for the unique subgame perfect equilibrium by backward induction. In round $n-1$, the party making the offer would hold the other to its expected round $n$ payoff and take for itself the expected "efficiency gain" (from agreement in round $n-1$ rather than round $n$ ), $\alpha$, plus its own expected round $n$ payoff. Similarly, in round $n-2$, the offering party would hold the other party to its expected round $n-1$ payoff (which is $\frac{1}{2} \alpha$ plus its expected round $n$ payoff, if it would make the offer in round $n-1$ with probability $\frac{1}{2}$ ) and take the balance. That balance amounts to the expected "efficiency gain" (from agreement in round $n-2$ rather than round $n-1$ ), $\alpha$, plus its own expected round $n-1$ payoff. Its expected round $n-1$ payoff, in turn, is also $\frac{1}{2} \alpha$ plus its expected round $n$ payoff, if it would make the offer in round $n-1$ with probability $\frac{1}{2} .{ }^{11}$

In sum, in each round, each party receives its expected round $n$ payoff plus $\alpha$ times the number of offers it would expect to make from the current round to round $n-1$. In round 1 , therefore, the equityholders receive their expected round $n$ payoff plus $\alpha$ times the number of offers they would expect to make before round $n$. Because each party would expect to make $\frac{1}{2}(n-1-e)$ offers

11. All expectations are taken conditional on information available at the time of the current offer, that is, in round $n-2$. Recall that by the law of iterated expectations, the expectation of an expectation conditional on more information is simply the unconditional expectation. In the example above,

$E_{n-2}\left[E_{n-1}\left[V X_{n}\right]\right]=E_{n-2}\left[V X_{n}\right]$. 
from round $e+1$ to round $n-1$, and the equityholders in addition would make all $e$ offers from round 1 to round $e$, the equityholders receive

$V E_{1}=\alpha e+\frac{1}{2} \alpha(n-1-e)+E_{1}\left[V E_{n}\right]$

and the debtholders receive

$V D_{1}=\frac{1}{2} \alpha(n-1-e)+E_{1}\left[V D_{n}\right]$

at the end of round 1. Moreover, because we assume liquidation is costless, (4) equals

$V E_{1}=\frac{1}{2} \alpha(e+n-1)+E_{1}\left[\max \left(0, V_{n}-D\right)\right]$,

and (5) equals

$\dot{V} D_{1}=\frac{1}{2} \alpha(n-1-e)+E_{1}\left[\min \left(D, V_{n}\right)\right]$.

The second term in (6) is the expected value of what equityholders would receive if there is no agreement through round $n$ and there is instead liquidation. In the alternative, we may express this expected value as

$E_{1}\left[\max \left(0, V_{n}-D\right)\right]=\operatorname{Pr}\left(V_{n}>D\right) E_{1}\left[V_{n}-D \mid V_{n}>D\right]$,

where $\operatorname{Pr}\left(V_{n}>D\right)$ is the probability of $V_{n}>D$. We can also express this expected value as a function of our basic parameters, making use of the particular probability distribution of $V_{n}$.

Lemma 1. The expected values of what the parties would receive from a costless liquidation if they failed to reach agreement by time $t=T$ are as follows:

$$
\begin{aligned}
E_{1}\left[\max \left(0, V_{n}-D\right)\right]= & \sum_{k=0}^{n-1}\left(\frac{1}{2}\right)^{n-1}\left(\begin{array}{c}
n-1 \\
k
\end{array}\right) \\
& \times \max \left[0, V_{1}-D-(\alpha+\theta)(n-1)+2 \theta k\right]
\end{aligned}
$$

for the equityholders, and

$$
\begin{aligned}
E_{1}\left[\min \left(D, V_{n}\right)\right]= & \sum_{k=0}^{n-1}\left(\frac{1}{2}\right)^{n-1}\left(\begin{array}{c}
n-1 \\
k
\end{array}\right) \\
& \times \min \left[D, V_{1}-(\alpha+\theta)(n-1)+2 \theta k\right]
\end{aligned}
$$

for the debtholders. 
Proof. Each round is a Bernoulli trial in which $\delta$ may take on one of two values with equal probability, so $n-1$ such trials from round 2 to round $n$ lead to $2^{n-1}$ equally likely sequences of $\delta_{i}$. Let $k$ represent the number of times $\delta$ takes on the high value, $\theta-\alpha$, from the end of round 1 to the end of round $n$, so that $n-1-k$ is the number of times it takes on the low value, $-\theta-\alpha$. The number of distinct sequences with the same $k$ is given by the binomial coefficient. Thus, $k$ is a random variable, taking values from 0 to $n$ -1 , that follows the binomial distribution:

$b(k, n-1)=\left(\frac{1}{2}\right)^{n-1}\left(\begin{array}{c}n-1 \\ k\end{array}\right)=\left(\frac{1}{2}\right)^{n-1} \frac{(n-1) !}{k !(n-1-k) !}$.

Given any set of values for the parameters known in round 1 , including $V_{1}$, there are $n$ possible values for $V_{n}$, because there are $n$ possible values for $k$ :

$$
\begin{aligned}
V_{n}(k) & =V_{1}-\alpha(n-1)+\theta k-\theta(n-1-k) \\
& =V_{1}-(\alpha+\theta)(n-1)+2 \theta k .
\end{aligned}
$$

Therefore, the probability of each $V_{n}(k)$ is given by the binomial formula in (11). Together (11) and (12) yield the above lemma.

Using (9) and (10) to substitute into (6) and (7), respectively, we can conclude with the following proposition.

Proposition 1. The two classes of claimants will adopt a reorganization plan in round 1, with the equityholders obtaining

$$
\begin{aligned}
V E_{1}= & \frac{1}{2} \alpha(e+n-1)+\sum_{k=0}^{n-1}\left(\frac{1}{2}\right)^{n-1}\left(\begin{array}{c}
n-1 \\
k
\end{array}\right) \\
& \times \max \left[0, V_{1}-D-(\alpha+\theta)(n-1)+2 \theta k\right],
\end{aligned}
$$

and the debtholders obtaining the complementary share:

$$
\begin{aligned}
V D_{1}= & \frac{1}{2} \alpha(n-1-e)+\sum_{k=0}^{n-1}\left(\frac{1}{2}\right)^{n-1}\left(\begin{array}{c}
n-1 \\
k
\end{array}\right) \\
& \times \min \left[D, V_{1}-(\alpha+\theta)(n-1)+2 \theta k\right],
\end{aligned}
$$

\subsection{The Sources of the Equityholders' Power}

Although debtholders' claims exceed the value of the firm in round 1, equityholders receive a round- 1 share greater than 0 . We can isolate two distinct sources of the equityholders' power to obtain more than its contractual right. The equityholders' share, $V E_{1}$ as expressed in (13), is composed of two terms. Each term corresponds to a different reason for equityholders to get a positive share even though $D>V_{1}$. (In Section 2.5, when we introduce the possibility 
that conversion to Chapter 7 liquidation may cause the firm to lose value, there will be a third source of the equityholders' power to obtain value.)

2.3.1 The Financial Distress Costs Created by Delay. The total "efficiency gains" from reaching agreement in round 1 rather than leaving the firm in Chapter 11 for $n$ rounds is $\alpha(n-1)$, because such agreement thereby avoids the deterioration in firm value that would occur during the next $n-1$ rounds. Because the consent of the equityholders is necessary to avoid incurring these financial distress costs, the equityholders can obtain part of these savings in exchange for that consent. The first term in (13) is the equityholders' share of these savings and represents the gain to equityholders from the presence of financial distress costs. If we let $\alpha$ go to 0 in the limit, then the savings from avoiding delay also go to 0 , and the equityholders would receive only the second term, $E_{1}\left[V E_{n}\right]$.

The first term in (13), $\frac{1}{2} \alpha(e+n-1)$, may be expressed as the sum of two elements, as in (4). First, during the first $e$ rounds, when the equityholders have the exclusive power to make offers, they expect to capture all the savings from agreement in round 1 rather than in round $e+1$. This surplus amounts to $\alpha e$. Second, during the last $n-e$ rounds, when both the equityholders and the debtholders can make offers, each class expects to capture half of the savings from agreement in round $e+1$ rather than in round $n$. Therefore, the equityholders can obtain half of this surplus, that is, $\frac{1}{2} \alpha(n-1-e)$, in round 1 .

2.3.2 The "Option Value" Created by Delay. The second term in (13) represents the gain to equityholders from the possibility of $V_{n}$ greater than $D$. The equityholders could deny their consent to any plan and delay a division of value until round $n$. Given the volatility of $V_{i}$, there is some chance that at the end of round $n, V_{n}$ will exceed $D$. Although the expected value of $V_{n}$ is less than $V_{1}$, the actual value of $V_{n}$ might exceed $V_{1}$ and even $D$. The Chapter 11 process, by giving the equityholders the ability to insist on delay, gives equityholders the option to receive the difference $V_{n}-D$. To give up this option, equityholders must get compensation in return.

Specifically, equityholders receive the expected value of $V E_{n}$, that is, the full value of the equityholders' "option." This "option value" is positive if and only if $\operatorname{Pr}\left(V_{n}>D\right)>0$. Furthermore, $\operatorname{Pr}\left(V_{n}>D\right)>0$ if and only if $V_{n}>$ $D$ when all uncertainty is resolved favorably, that is, $\delta=\theta-\alpha$ in each round, so that $k=n-1$ in (12). Therefore, the following two conditions are equivalent:

$$
\operatorname{Pr}\left(V_{n}>D\right)>0 \Leftrightarrow(n-1)(\theta-\alpha)>D-V_{1} .
$$

\subsection{Comparative Statics}

The equityholders' share of $V_{1}$ consists of two terms that depend on the following parameters: (i) the initial undercoverage of debt, $D-V_{1}$; (ii) the volatility of the firm's value from period to period, $\theta$; (iii) the financial distress costs per unit of time $\Delta t, \alpha$; (iv) the length of the reorganization 
period measured in rounds of bargaining, $n$; and (v) the length of the period during which the equityholders control the agenda, also measured in rounds of bargaining, $e$. We will now examine how each of these parameters affects the equityholders' share, $V E_{1}$.

2.4.1 The Initial Undercoverage of Debt. By the initial undercoverage of debt, we mean the extent to which the debt exceeds the value of the firm's assets at the end of round $1, D-V_{1}$.

Proposition 2. The share of $V_{1}$ obtained by equityholders, $V E_{1}$, is nonincreasing in $D-V_{1}$ (and thus in $D$ ). Furthermore, if there is a positive probability that $V_{n}$ will exceed $D$, then $V E_{1}$ is decreasing in $D-V_{1}$ (and thus in $D) .{ }^{12}$

Remark. The intuition underlying Proposition 2 is as follows. A rise in $D-$ $V_{1}$ affects only the second term in (13). In particular, it shifts down the entire probability distribution of $V_{n}-D$ in the expression for the equityholders' "option value" in (13). That "option value" arises from the possibility of $V_{i}$ rising from $V_{1}$ to above $D$ due to positive shocks. Because a higher $D-V_{1}$ makes this event less likely, it reduces this "option value." Thus, as shown in the proof, a rise in $D-V_{1}$ cannot make equityholders better off, and if $D-$ $V_{1}$ is small enough to imply $\operatorname{Pr}\left(V_{n}>D\right)>0$, then such a rise must cause their "option value" (and their share of $V_{1}$ ) to decrease.

Proof. See the Appendix.

2.4.2 The Volatility of Firm Value. The volatility of the firm's value over time, represented by $\theta$, depends upon the nature of the firm's business and thus may vary greatly from firm to firm.

Proposition 3. The share of $V_{1}$ obtained by equityholders, $V E_{1}$, is nondecreasing in $\theta$. Furthermore, if there is a positive probability that $V_{n}$ will exceed or equal $D$, then $V E_{1}$ is increasing in $\theta .{ }^{13}$

Remark. The intuition underlying Proposition 3 is as follows. The volatility of the firm's value affects only the second term in (13). As shown in the proof, the greater that volatility, $\theta$, the greater the likelihood that $V_{n}$ will exceed $D$, and the greater will be the equityholders' "option value." Thus, a rise in $\theta$ must leave equityholders at least as well off as before, and if $\theta$ is large enough

12. Specifically, if $D-V_{1}<(n-1)(\theta-\alpha)$, then $\operatorname{Pr}\left(V_{n}>D\right)>0$, and increasing $D-V_{1}$ will cause $V E_{1}$ to decrease. If $D-V_{1} \geq(n-1)(\theta-\alpha)$, then $\operatorname{Pr}\left(V_{n}>D\right)=0$, and further increasing $D-V_{1}$ will have no effect on $V E_{1}$.

13. Specifically, if $\theta<\alpha+\left(D-V_{1}\right) /(n-1)$, then $\operatorname{Pr}\left(V_{n} \geq D\right)=0$, and increasing $\theta$ will have no effect on $V E_{1}$. If $\theta \geq \alpha+\left(D-V_{1}\right) /(n-1)$, then $\operatorname{Pr}\left(V_{n} \geq D\right)>0$, and increasing $\theta$ will cause $V E_{1}$ to increase. 
to imply $\operatorname{Pr}\left(V_{n} \geq D\right)>0$, then their "option value" (and their share of $V_{1}$ ) must increase in $\theta$.

Proof. See the Appendix.

2.4.3 The Financial Distress Costs. The financial distress costs per unit of time that the firm remains in Chapter $11, \alpha$, are likely to vary greatly among firms. For example, a company that owns a number of buildings leased under long-term leases would incur small financial distress costs (because few transactions would have to take place during the Chapter 11 period) relative to a company that deals frequently with many business partners and makes frequent investment decisions.

Proposition 4. The share of $V_{1}$ obtained by equityholders, $V E_{1}$, is increasing in $\alpha$.

Remark. The intuition underlying Proposition 4 is as follows. The size of the financial distress costs, $\alpha$, will affect both terms in (13). Thus, a rise in $\alpha$ has two effects. On the one hand, it increases the financial distress costs that can be saved if the equityholders consent to a plan, thus improving their bargaining position. On the other hand, it decreases their "option value" because it makes it less likely that $V_{i}$ can climb beyond $D$. If $\alpha$ increases to the point that $\operatorname{Pr}\left(V_{n}>D\right)=0$, then the equityholders' share is affected by $\alpha$ only through the first effect and therefore a rise in $\alpha$ makes equityholders unambiguously better off. Furthermore, as shown in the proof, the positive effect is always greater than the negative effect, because the financial distress costs are more likely to fall on the debtholders than on the equityholders. Therefore, the equityholders' share increases in $\alpha$.

Proof. See the Appendix.

2.4.4 The Length of the Reorganization Period. The length of the reorganization period, represented in our model by $T$ (or equivalently by the number of rounds $n$ ), depends on how long the bankruptcy court will wait, in the face of failure to work out a reorganization plan, before converting from Chapter 11 to Chapter 7. Let us consider increases in $T$ by multiples of $\Delta t$, which would cause $n$ to rise by an integer, so as to maintain the structure of the model, which assumes that $n$ is an integer.

Proposition 5. The share of $V_{1}$ obtained by equityholders, $V E_{1}$, is increasing in $n$.

Remark. The intuition underlying Proposition 5 is as follows. A rise in $T$ affects both terms in (13) through $n$. First, it raises the total financial distress costs that the firm would incur if equityholders never gave their consent to a plan. This effect strengthens their bargaining power. Second, once $\operatorname{Pr}\left(V_{n}>D\right)$ 
$>0$, an increase in $n$ also would have an effect on their "option value." As shown in the proof, some increases will cause an upward change in the "option value" (because high values for $V_{n}$ become more likely) whereas others will cause a downward change (because the expected value of $V_{n}$ falls). We show in the proof, however, that even in the case of a downward change, the overall effect on the equityholders' share is positive. In those cases in which a rise in $n$ causes the equityholders' "option value" to fall, the positive effect upon the equityholders' share of the "efficiency gains" would be greater than the absolute value of the negative effect, because the costs of delay would be more likely to fall on the debtholders than on the equityholders.

Proof. See the Appendix.

2.4.5 The Initial Agenda Control. As already noted, the equityholders have control over the agenda for the first six months of bargaining, and the courts often extend this period. Our model captures this feature of Chapter 11 by assuming that all offers in the first $e$ rounds, $0<e<n$, must be made by the equityholders. ${ }^{14}$ The size of $e$ depends on the courts' willingness to extend the initial six-month period.

Proposition 6. The share of $V_{1}$ obtained by the equityholders, $V E_{1}$, is increasing in $e$. Specifically, any unit increase in $e$ causes $V E_{1}$ to increase by $\frac{1}{2} \alpha$.

Remark. The intuition underlying Proposition 6 is as follows. Control over the reorganization agenda is valuable. During each round in which the equityholders have this control, they would capture all of the financial distress costs, $\alpha$. In any round in which both sides can make offers, however, the equityholders expect to capture only $\frac{1}{2} \alpha$. The incremental gain to the equityholders from any unit increase in $e$ is therefore $\frac{1}{2} \alpha$. The greater are the financial distress costs, the greater is the value of this unit increase (the derivative of the equityholders' gain with respect to $\alpha$ is $\frac{1}{2}$ ). Furthermore, a higher $e$ implies that a rise in $\alpha$ benefits equityholders even more than it would otherwise, because only they gain bargaining power from the deterioration of firm value from round 1 to round $e+1$. The derivative of the "efficiency gains" component in (13) with respect to $\alpha$ is $\frac{1}{2}(e+n-1)$, and each unit increase in $e$ raises this derivative by $\frac{1}{2}$.

Proof. The proof is clear from the above remark.

14. In reality, the incumbent management controls the agenda during this initial period, but we have assumed that managers act on behalf of the equityholders. One could easily adjust the model to suit alternative assumptions. For example, consider a case in which the debt is held by a bank which the managers expect to hold most of the stock of the company after reorganization. In this case, one might assume that the management, in making offers during the period in which it controls the agenda, would serve the interests of the debtholders. As a result, the debtholders rather than the equityholders would capture all the surplus $\alpha e$ that is created by avoiding the financial distress costs that would be incurred during the initial period. 


\subsection{Loss from Chapter 7 Liquidation}

Until now we have assumed that a sale of the firm's assets under Chapter 7 would not impose any efficiency loss. That is, we assumed that after $n$ rounds a Chapter 7 sale would produce a value of $L=V_{n}$. This assumption would be reasonable if one adopted the view of Baird (1986) and Jackson (1986: chap. 9). According to that view, there is no reason to expect that a sale under Chapter 7 , properly administered, would produce a value significantly below the firm's going-concern value. If the firm has greater value as a going concern, then the assets would be sold as a going concern.

This view of Chapter 7, however, is by no means universally accepted. Many scholars and players in corporate insolvency believe, correctly or incorrectly, that Chapter 7 would involve some efficiency loss-that is, it might not bring in the full value $V_{n}$. For this reason, we now introduce the possibility that a Chapter 7 sale at $t=T$ would produce a value $L<V_{n} \cdot{ }^{15}$ Specifically, let $L=V_{n}-\lambda$, where $0 \leq \lambda<V_{1}-(n-1)(\theta+\alpha)$, so that $0<L \leq V_{n}$ in all states of the world, that is, for any $k$. All other assumptions are as before. Using the same methods as those in Section 2.2, we find that the loss in value from liquidation introduces a third source of the equityholders' bargaining power.

Proposition 7. If the two classes of claimants expect a Chapter 7 sale to involve a loss of value $\lambda$, then they will adopt a reorganization plan in round 1 , with the equityholders obtaining

$$
\begin{aligned}
V E_{1}= & \frac{1}{2} \alpha(e+n-1)+\frac{1}{2} \lambda+\sum_{k=0}^{n-1}\left(\frac{1}{2}\right)^{n-1}\left(\begin{array}{c}
n-1 \\
k
\end{array}\right) \\
& \times \max \left[0, V_{1}-D-\lambda-(\alpha+\theta)(n-1)+2 \theta k\right] .
\end{aligned}
$$

Proof. See the Appendix.

Let us now examine the change that is introduced by the loss $\lambda$ from Chapter 7. As the following proposition indicates, the equityholders' share of $V_{1}$ tends to be larger as this loss is larger.

Proposition 8 . The share of $V_{1}$ obtained by equityholders, $V E_{1}$, is nondecreasing in $\lambda$. Thus, the equityholders are at least as well off when $\lambda>0$ as they are when $\lambda=0$. Furthermore, if the probability that $L$ will exceed $D$ is less than $\frac{1}{2}$, as is likely, then $V E_{1}$ is increasing in $\lambda .{ }^{16}$

15. Furthermore, to the extent that liquidation does not occur immediately upon rejection of the last offer in round $n$, the firm would incur some financial distress costs between the end of round $n$ and liquidation. In the altemative, then the possibility of $L<V_{n}$ could represent the deterioration in the firm's value between the end of round $n$ and liquidation.

16. In particular, if $\left(D-V_{1}\right)+\alpha(n-1)+\lambda \geq \theta$, as is likely, then $\operatorname{Pr}(L>D)<\frac{1}{2}$, and $V E_{1}$ is increasing in $\lambda$. 
Remark. The intuition underlying Proposition 8 is as follows. The expectation of the liquidation loss $\lambda$ would strengthen the equityholders' bargaining power and thereby increase their share, $V E_{1}$. Without their consent to a reorganization plan, the firm would not only suffer financial distress costs for $n$ rounds, but would also suffer the losses from a Chapter 7 sale for less than the firm's full value. Thus, the equityholders' consent can save the firm the liquidation loss, $\lambda$, and therefore they can expect to capture some part of these savings in exchange for their consent. At the same time, in our model, such a liquidation loss would reduce the equityholders' "option value," $\left.E_{1} \mid V E_{L}\right]$. As shown in the proof, however, the positive effect is at least as great as the negative effect on this "option value." Furthermore, under conditions that ensure $\operatorname{Pr}(L>D)<\frac{1}{2}$, which is likely to hold for plausible parameter values, the positive effect must strictly dominate the negative effect, because then the loss would be more likely to fall on the debtholders than on the equityholders.

Proof. See the Appendix.

\subsection{Renegotiation Prior to Chapter 11 Filing}

Our model has assumed that the bargaining game begins upon the firm's filing under Chapter 11. One might consider, however, whether the parties would renegotiate their claims prior to filing under Chapter 11 (see, e.g., Berkovitch and Israel, Bergman and Callen, and Giammarino). To the extent that some financial distress costs are incurred prior to the filing, as is likely as the company approaches insolvency, the parties would have much to gain from such an earlier renegotiation. By this reasoning, if the parties know that once there is filing for Chapter 11 the firm's value will be divided in a certain way, then there will be no such filing because they will agree to such a division beforehand. Brown, for example, assumes in his model that such renegotiation will always take place.

Various factors, however, suggest that such renegotiation may not succeed outside of Chapter 11, because there may be a "free rider" or "holdout" problem (see Gertner and Scharfstein; Gilson, John, and Lang). Consequently, renegotiation would instead take place, as in our model, only after the filing, and in accordance with the rules governing Chapter 11 reorganization. Outside of Chapter 11, each debtholders' claim cannot be waived unless the debtholder individually consents. Thus, each debtholder may hold out, preferring that other debtholders make the necessary concessions. In contrast, under Chapter 11 a provision for majority rule solves this collective-action problem: the specified majority in any given class can vote to make concessions on behalf of each of the members of the class, without the unanimous consent of its members, and can thereby impose the plan on its members who dissent. ${ }^{17}$

17. Similarly, contractual mechanisms could solve this collective-action problem outside of Chapter 11. The Trust Indenture Act, however, prohibits contractual provisions that would enable the majority of bondholders to concede any part of the principal on the bonds. As Roe notes, the unanimous approval requirements of that law may generate holdout problems within a class and thereby inhibit a troubled firm's ability to avert bankruptcy proceedings. 
Thus, although the parties may renegotiate their claims before filing for Chapter 11 to avoid excessive delay within Chapter 11 , they will face the problem of holdouts. To solve this problem, the company may file for Chapter 11 so that a majority vote on the proposed plan would bind all members within each class. Through this mechanism, the negotiating parties can settle on a reorganization plan before the filing, then have the prepackaged plan confirmed within Chapter 11. See Broude (1990:§11.06). Nevertheless, as the parties formulate the prepackaged plan, they would anticipate the outcome of Chapter 11 bargaining. Thus, under such prepackaged plans, the equityholders would not receive less than they would expect from Chapter 11 bargaining.

\subsection{Chapter 11 Filing by "Solvent" Companies}

Thus far we have assumed that upon filing for reorganization, the value of the firm's assets is less than its debt: $V<D$. A company, however, need not be insolvent to file under Chapter 11 , and observers generally believe that some firms file with $V \geq D$. We now sketch briefly what our model suggests with respect to the outcome of such a filing (and the ex ante incentive on the part of equityholders to have such a filing).

Suppose that a firm files for Chapter 11 with $V \geq D$, but with $V$ still small enough to cause financial distress costs. Our model can be easily extended to analyze the bargaining game following such a filing. As before, the parties would understand that delay in adopting a reorganization plan would have two consequences: the firm would incur financial distress costs, and uncertainty would be resolved. Therefore, the outcome of the game would still be the partition described in Proposition 1. The interesting question, however, is whether this expected outcome of the bargaining game would lead equityholders to favor a filing for Chapter 11 .

The partition predicted by Proposition 1 for $V \geq D$ suggests two possibilities. If $V$ is sufficiently close to $D$, the equityholders can still get more than their contractual right, $V-D$. Uncertainty would work in favor of the equityholders through the "option value" element. Moreover, if $V$ is sufficiently close to $D$ (or if the financial distress costs $\alpha$ are large enough), then the erosion in value that would result from a delay in reorganization for a period $T$ would come mostly at the expense of the debtholders. Consequently, the debtholders would make concessions-agree to be paid less than their contractual right - and the equityholders would thus obtain more than their contractual right. Given this expected outcome, it would be in the equityholders' interest in such a case for the company's management to file for Chapter 11.

If $V$ is not sufficiently close to $D$, however, and the company files for Chapter 11 , then the outcome of the bargaining game would be unfavorable for the equityholders. For in such a case, the prospect of financial distress costs would work against the equityholders in the bargaining, because the equityholders would be expected to bear most of these costs. Consequently, the outcome predicted by Proposition 1 might be one in which the debtholders 
obtain more (and the equityholders less) than their contractual right. Such Chapter 11 cases, however, might not actually arise. In such cases, the interest of equityholders would not be served by the company filing for Chapter 11 - they would prefer to have the company pay the debt in full, raising the necessary funds by selling assets or issuing extra equity. Thus, to the extent that management seeks to advance the interests of the equityholders, one would not expect the company to file for Chapter 11 in such cases. ${ }^{18}$

\subsection{Informal Offers and Agenda Control}

One feature of Chapter 11 that we sought to represent in our model is the fact that during a certain period only the company could propose reorganization plans. We assumed that the equityholders would make all offers during this period, because we assumed that the company's management acts in the interests of the equityholders. We assumed that thereafter either one class or the other would have control of the bargaining agenda during each bargaining round, and that the procedural rules governing formal proposals determined the duration of these rounds.

One might argue, however, that the model should not feature such exclusive agenda control, in light of the possibility of informal offers. For example, although the debtholders cannot formally propose plans in the initial period during which the company has an exclusive right to do so, they can tell the company informally what plans they would be willing to accept. Therefore, in spite of the exclusive control of the formal agenda under Chapter 11, one might model the bargaining as a symmetric game in which both sides may make offers. According to this view, the legal monopoly over the formal agenda is practically meaningless.

Such a change in assumptions would require only minor modifications in our model, because exclusive agenda control is not a critical element of the model. If both classes may make offers throughout the bargaining period, then each would simply obtain half of the savings created by avoiding the financial distress costs during this period. Nevertheless, because the provision for exclusive agenda control during the initial period often arises in policy discussions, we should explain why in our view, in spite of the possibility of informal offers, control over the formal agenda is important in practice and may give a significant bargaining advantage to the party with this control.

When one class proposes a formal plan under Chapter 11, the other class must decide whether to accept, after the delay required by law. Each knows that rejection would result in the extra delay required for another proposal and another vote. The class that proposes the plan can capture almost all the surplus created by avoiding the delay, because the other class would rather accept any small share of the surplus than reject the plan and lose the surplus.

Of course, informal offers may precede a formal proposal, but unlike a formal plan, an informal offer cannot be accepted by a binding class vote. The 
"acceptance" of an informal offer thus lacks the legal implications of the acceptance of a formal offer: an informal acceptance cannot partition the company's value nor bring the company out of Chapter 11. An informal proposal is merely a suggestion for the other side to make a particular formal proposal. Regardless of such suggestions, the party making the formal proposal can be expected to propose the plan most favorable to the proposing party among those that the other party would rationally accept ${ }^{19}$ Informal proposals cannot affect this plan if (as is the case in our setting) there is no mechanism by which the party making an informal proposal can make a credible commitment to reject any less favorable proposal. ${ }^{20}$ Moreover, as long as the debtholders have no private information (as is the case in our setting), an informal offer by them cannot convey any information.

In sum, the possibility of informal offers does not render control over the formal agenda meaningless. This formal control may well give an important bargaining advantage to the party exercising this control. ${ }^{21}$ Therefore, we have sought to capture this effect in our model.

\subsection{Delay in Reaching Agreement on a Plan}

In the model, because it was assumed that there was no asymmetric information, the resolution of the bargaining occurred in round 1. Suppose one were to introduce asymmetric information about the firm's value $V$. For example, suppose that the equityholders (or more precisely, the management of the debtor who might be acting in their interests) have some private information not held by the debtholders. In this case, the sequential bargaining literature suggests that reaching an agreement may well take some time (as indeed often happens in reality ${ }^{22}$ ) and that the parties will incur significant efficiency costs. See, for example, Grossman and Perry, Fudenberg and Tirole, and Crampton. ${ }^{23}$

19. Consider a company in which the value of the assets is $\$ 100$. Suppose that in one month the court will convert the Chapter 11 proceeding to Chapter 7 , and that $\$ 30$ would be lost in liquidation, leaving only $\$ 70$ for the debtholders. Suppose also that one month must pass between the formal proposal by the equityholders and a vote on that proposal. The equityholders would propose a plan that would give them almost $\$ 30$ and leave slightly more than $\$ 70$ for the debtholders. Even if the debtholders had suggested informally a plan that would give them more, say $\$ 75$, the equityholders would have no reason to modify their plan, because they know that at the end of the month the debtholders would rationally vote to accept any amount greater than $\$ 70$.

20. Informal offers would serve a purpose, however, if the debtholders can commit not to give up more than a certain fraction of the surplus. For example, a bank may be a repeat player in Chapter 11 reorganizations and may have a reputation that enables it to make such a credible commitment. In such a case, the bank can insist on a particular fraction of the surplus and communicate informally its position. To succeed, however, the bank must have not only the ability to make informal offers but also the ability to make such a commitment.

21. Even prepackaged plans formulated before filing for Chapter 11 would reflect the bargaining advantage that the equityholders would enjoy through their exclusive control over the agenda during the initial period under Chapter 11. See Section 2.6.

22. White $(1984: 35,37)$ found the average length of the reorganization period, from bankruptcy filing to confirmation of a plan, to be 17 months. See also Franks and Torous (1989:753).

23. Since writing this article, we learned of the work of Kaiser in the direction outlined above $\mathrm{He}$ introduces asymmetric information in a bargaining model of reorganization and confirms that 
The structure imposed upon the bargaining by Chapter 11 is crucial to this result. Gul and Sonnenschein point out that asymmetric information between bargaining parties cannot by itself explain delay in reaching agreement, because as the length of each round is allowed to go to 0 , so does the total delay. This objection does not apply to the reorganization context, however, because the legal rules governing Chapter 11 bargaining imply that, unlike the case in other contexts, there is a limit to how short the bargaining rounds can be.

\section{Concluding Remarks}

In this article, we have sought to develop a sequential bargaining model of the Chapter 11 negotiation process, to show the effects of the legal rules that govern this process, and to determine the shares of the firm's value that equityholders and debtholders may expect to receive under a reorganization plan. The model has identified and analyzed three possible sources of the equityholders' power to obtain value under Chapter 11 even if the value of the firm's assets is less than its debt: if they were to delay or prevent agreement, (i) the firm would incur financial distress costs, (ii) the volatility of its assets' value may create some probability that the firm becomes solvent, and (iii) a Chapter 7 sale may entail a loss in value.

Our analysis has identified how various features of the company shape the Chapter 11 division of value. Our results regarding the effects of the company's features provide testable implications of the model. In particular, one could test the hypotheses that equityholders tend to capture a larger fraction of the value of the reorganized company when (i) the value of the company's assets is volatile (as measured, say, by the past volatility of the company's total stock and bond value), (ii) the nature of the company's business is such that financial distress costs are likely to be relatively high, or (iii) the total value of the reorganized company is a relatively large fraction of the outstanding debt. ${ }^{24}$

We have also analyzed how the various features of the legal regime contribute to the equityholders' ability to extract value, and our analysis reveals how changes in this regime would affect the equityholders' share. The length of the reorganization period - the time that the parties expect the court to allow them

significant delay can result. Kaiser focuses on the possibility of delay and the factors that determine the length of this delay, not on the factors that determine the division of value between equityholders and debtholders. Thus, his article complements this article.

24. Recent empirical studies of Chapter 11 have confirmed that equityholders obtain more than their contractual right, but have not tested any of these three hypotheses. Our preliminary analysis of the data presented in Table II of Eberhart, Moore, and Roenfeldt (1990:1463) offers some support for hypothesis (iii). A simple linear regression on their 30 observations reveals that the extent to which senior claims (those of creditors and of preferred shareholders) exceed total value (expressed as a percent of total value) has a statistically significant negative effect upon the percent of total value paid to common shareholders: we find the relevant coefficient to be -0.04727 , with a standard error of 0.02428 . If we restrict the sample to the 18 cases of insolvent companies, the regression again reveals a negative effect, but it is no longer statistically significant: we find the coefficient to be -0.00729 , with a standard error of 0.01267 . A proper hypothesis test, however, would require data on all explanatory variables that the model indicates we should include in the regression. 
to remain in Chapter 11 , without adopting a plan, before converting to Chapter 7 -proves to be a critical feature. We find that any change in judicial attitudes that would shorten this period would decrease the equityholders' share. In addition, the equityholders benefit from their control over the agenda during the initial period; thus, any reduction in the length of this period would tend to shift the division of value in favor of the debtholders. ${ }^{25}$

The normative question remains: Is the ability of the equityholders to receive more than their contractual right in Chapter 11 undesirable? One perspective from which this question may be evaluated is distributional; that is, it may be asked whether creditors are treated unfairly. With respect to most voluntary creditors, the answer may well be no, because the terms of their contracts will likely take the possibility of Chapter 11 into account. In particular, lenders will likely anticipate the outcome of possible Chapter 11 proceedings and charge a higher interest rate than they would in the absence of Chapter 11. But companies often have also involuntary creditors, such as tort victims, who cannot protect themselves contractually as voluntary creditors can. Chapter 11 does transfer wealth from involuntary creditors to equityholders.

Another perspective from which the distributional consequences of Chapter 11 may be evaluated is that of efficiency. The expectation that equityholders will be able to use Chapter 11 to obtain more than their contractual right may affect the investment and management decisions that managers and equityholders make ex ante, either in the financial distress period preceding the filing for Chapter 11 (see Gertner and Scharfstein) or even prior to the onset of financial distress (see Bebchuk, 1991). Consequently, the division of value in Chapter 11, on which the analysis of this article has focused, may well have significant ex ante efficiency effects.

\section{Appendix}

In this appendix we derive several propositions, including our comparative statics results. To analyze the effect of the parameters on $V E_{1}$, it will prove useful to make some preliminary observations. Consider the general model in Section 2.5, in which $\lambda \geq 0$ and $L \leq V_{n}$. (To apply the following reasoning to the model in Section 2.4, which addresses a special case of the more general model, let $\lambda=0, L=V_{n}$, and $V E_{L}=V E_{n}$.)

First, we derive a lemma pertaining to the "option value" component of $V E_{1}$. Note that $V E_{L}$ is a continuous function of $L-D$. In particular, as the parameters change, $V E_{L}$ will equal (and therefore increase and decrease onefor-one with) $L-D$ if $L>D$, will remain constant at 0 if $L<D$, and will

25. Only a more radical reform of Chapter 11 , however, can ensure that all participants receive their contractual rights. Under any regime in which the consent of the equityholders is necessary to avoid delay in the firm's reorganization, the equityholders will be able to extract some value above their contractual right. Thus, Bebchuk (1988) proposes a method of reorganization based not on bargaining but on the distribution of particular securities to the participants. This reform would produce a distribution of value fully consistent with all the participants' contractual rights. 
increase one-for-one (but not decrease) with $L-D$ if $L=D$. Therefore, we can state the following lemma.

Lemma $A 1$. For any parameter $x$ that does not affect the probability distribution of the random variable $k$ - that is, for $D-V_{1}, \theta$, and $\alpha$ - the following holds for increases in $x:^{26}$

$$
\begin{aligned}
\frac{\partial E_{1}\left[V E_{L}\right]}{\partial x}=E_{1}\left[\frac{\partial V E_{L}}{\partial x}\right]= & \operatorname{Pr}(L=D) \max \left[0,\left.\frac{\partial(L-D)}{\partial x}\right|_{L=D}\right] \\
& +\operatorname{Pr}(L>D) E_{1}\left[\frac{\partial(L-D)}{\partial x} \mid L>D\right]
\end{aligned}
$$

Second, we will find it useful to place an upper limit on $\operatorname{Pr}(L>D)$. Given the symmetric probability distribution of $k$, if $n$ is odd, then the median value for $k$ is $E_{1}[k]=\frac{1}{2}(n-1)$. In that case, the median value for $L$ is similarly $E_{1}[L]=V_{1}-\alpha(n-1)-\lambda$, which must be less than $D$. Therefore, if $n$ is odd, then $\operatorname{Pr}(L>D)<\frac{1}{2}$.

If $n$ is instead even, then there is no unique median value for $k$. In this case, $\operatorname{Pr}(L>D)<\frac{1}{2}$ if and only if $L \leq D$ for $k=\frac{1}{2} n$. As one can see from (12), if $k$ $=\frac{1}{2} n$, then $V_{n}=V_{1}-\alpha(n-1)+\theta$. Therefore, if $\left(D-V_{1}\right)+\alpha(n-1)+$ $\lambda \geq \theta$, then $\operatorname{Pr}(L>D)<\frac{1}{2}$. Furthermore, $\operatorname{Pr}(L>D)>\frac{1}{2}$ would require that $L$ $>D$ for $k=\frac{1}{2}(n-2)$. As one can see from (12), however, if $k=\frac{1}{2}(n-2)$, then $V_{n}=V_{1}-\alpha(n-1)-\theta$, which must be less than $D$. Therefore, $\operatorname{Pr}(L>D)>\frac{1}{2}$ is impossible. We summarize these results in the following lemma.

Lemma A2. $\operatorname{Pr}(L>D) \leq \frac{1}{2}$, and $\operatorname{Pr}(L>D)<\frac{1}{2}$ if and only if either $\left(D-V_{1}\right)+\alpha(n-1)+\lambda \geq \theta$ or $n$ is odd.

Using Lemmas A1 and A2, we can now provide proofs of the propositions stating our comparative statics results.

Proof of Proposition 2. Note that the derivative of $V_{n}-D$ with respect to $D-V_{1}$ is -1 in any state of the world, that is, for any $k$. Therefore, recalling that $V E_{L}=V E_{n}$ and $L=V_{n}$, and using Lemma $\mathrm{A} 1$,

$\frac{\partial E_{1}\left[V E_{1}\right]}{\partial\left(D-V_{1}\right)}=-\operatorname{Pr}\left(V_{n}>D\right)$.

26. The notation for the partial derivative of $V E_{L}$ (or its expected value) in this lemma and in the proofs below will represent the limit of $\Delta V E_{L} / \Delta x$ as we approach $x$ from the right side, in order to describe the effects of an increase in $x$. To describe decreases in $x$, we would approach $x$ from the left side and would replace "max" in (A1) with "min." These two limits are not equal [i.c., although $V E_{L}(x)$ is continuous, it is not differentiable] at values of $x$ where $\operatorname{Pr}(L>D)$ changes, because this probability changes only in discrete amounts. 
Thus, increases in $D-V_{1}$ will decrease the equityholders' "option value" until $D-V_{1} \geq(n-1)(\theta-\alpha)$. At that point, by (15), the probability of $V_{n}>$ $D$ (and the "option value") reaches 0 , and by (A2), increases in $D-V_{1}$ then will have no further effect.

Proof of Proposition 3. First, note that the partial derivative of $V_{n}$ in (12) with respect to $\theta$ is $2 k-(n-1)$, which is greater or less than 0 as $k$ is greater or less than $\frac{1}{2}(n-1)$. That is, $V_{n}$ increases in $\theta$ in those states of the world in which $k$ is larger than $E_{1}[k]=\frac{1}{2}(n-1)$, which by (12) are those states in which $V_{n}$ is larger than $E_{1}\left[V_{n}\right]=V_{1}-\alpha(n-1)$. Because $V_{n}$ can affect $E_{1}\left[V E_{n}\right]$ only in those states in which $V_{n}$ exceeds or equals $D$, which in turn exceeds $V_{1}-\alpha(n-1)$ (indeed, exceeds $\left.V_{1}\right), \theta$ can affect $E_{1}\left[V E_{n}\right]$ only in those states in which $V_{n}$ is increasing in $\theta$. In the relevant states, therefore, $2 k-(n-1)>0$, and a rise in $\theta$ can only increase $V_{n}-D$ in the expression for the equityholders' "option value" in (13). Recalling that $V E_{L}=V E_{n}$ and $L=V_{n}$, and using Lemma $\mathrm{Al}$, then

$\frac{\partial E_{1}\left[V E_{n}\right]}{\partial \theta}=\operatorname{Pr}\left(V_{n} \geq D\right) E_{1}\left[2 k-(n-1) \mid V_{n} \geq D\right]$.

Furthermore, by reasoning analogous to that used to derive (15), the following two conditions are equivalent:

$\operatorname{Pr}\left(V_{n} \geq D\right)>0 \Leftrightarrow(n-1)(\theta-\alpha) \geq D-V_{1}$.

A rise in $\theta$, by (A3) and (A4), will have no effect on the expected value of $V E_{n}$ until $\theta \geq \alpha+\left(D-V_{1}\right) /(n-1)$; further increases will raise equityholders' "option value."

Proof of Proposition 4. First, note that the equityholders' "option value" is nonincreasing in $\alpha$. A rise in $\alpha$ shifts the entire probability distribution of $V_{n}$ downward and so reduces $V_{n}-D$ in the expression for the equityholders' "option value" in (13). In all states of the world, that is, for any $k$, the derivative of $V_{n}-D$ with respect to $\alpha$ will be $-(n-1)$. Recalling that $V E_{L}=$ $V E_{n}$ and $L=V_{n}$, and using Lemma $\mathrm{Al}$, then

$\frac{\partial E_{1}\left[V E_{n}\right]}{\partial \alpha}=-(n-1) \operatorname{Pr}\left(V_{n}>D\right)$.

Thus, $\alpha$ will have no effect if $\operatorname{Pr}\left(V_{n}>D\right)=0$ already. That is, by (15), an increase in $\alpha$ will reduce the "option value" until $\alpha \geq \theta+\left(V_{1}-D\right) /(n-1)$. Then the "option value" will be 0 , and further increases in $\alpha$ will have no effect on it.

It will be useful to place an upper limit on the absolute value of the negative effect of $\alpha$ on the "option value." By Lemma A2, $\operatorname{Pr}\left(V_{n}>D\right)$ can be at most $\frac{1}{2}$. Therefore, (A5) implies that the derivative of $E_{1}\left[V E_{n}\right]$ with respect to $\alpha$ can range from 0 to $-\frac{1}{2}(n-1)$. 
The full effect of $\alpha$ on the equityholders' share, unlike the effect of $\theta$ or of $D-V_{1}$, will also depend on an effect on the "efficiency gains" component, that is, the first term in (13). An increase in $\alpha$ has an unambiguously positive effect on this component of the equityholders' share: the derivative of $\frac{1}{2} \alpha(e+n-1)$ with respect to $\alpha$ is $\frac{1}{2}(e+n-1)$. This effect will always be greater than the absolute value of the negative effect on the "option value" component in (13), because $e>0$.

Proof of Proposition 5. By (15), the "option value" component of the equityholders' share will remain at 0 until $n>1+\left(D-V_{1}\right) /(\theta-\alpha)$. Once $n$ rises above this level, their expected round $n$ payoff rises above 0 . Thus, at that point the "option value" increases in $n$.

The "option value," however, will not be monotonically nondecreasing in $n$. Instead, it may decrease in particular cases. Note that $E_{1}\left[V_{n}\right]=V_{1}-$ $\alpha(n-1)$, so that each unit increase in $n$ causes the expected value of $V_{n}$ to fall by $\alpha$. Indeed, an increase from $n=N$ to $n=N+1$ will reduce the expected value of $V_{n}$, conditional on any particular $V_{N}$, by the amount $V_{N}-E_{N}\left[V_{N+1}\right]$ $=\alpha$. Therefore, it is easy to construct cases in which the expected value of $V_{n}$, conditional on $V_{n}>D$, will fall with an increase from $n=N$ to $n=N+$ 1. The equityholders' expected round $n$ payoff will then fall, provided that $\operatorname{Pr}\left(V_{n}>D\right)$ does not rise.

It will prove useful to place a ceiling on the absolute value of the negative effect that $n$ may have on the equityholders' "option value." A unit rise in $n$ cannot cause the expected value of $V_{n}$, conditional on $V_{n}>D$, to fall by more than $\alpha$. Thus, a rise in $n$ from $N$ to $N+1$ can reduce $E_{1}\left[V E_{n}\right]$ by at most $\alpha \operatorname{Pr}\left(V_{N}>D\right)$, because it can only reduce $V E_{n}$ in those states of the world in which $V_{n}>D$. Recall also that Lemma A2, with $\lambda=0$ and $L=V_{n}$, implies that $\operatorname{Pr}\left(V_{n}>D\right)$ can never exceed $\frac{1}{2}$ and can equal $\frac{1}{2}$ only if $n$ is even. Therefore, if $\operatorname{Pr}\left(V_{n}>D\right)$ equals $\frac{1}{2}$, then a rise in $n$ from $N$ to $N+1$ results in an odd $n$, so the median $V_{N+1}$ is strictly less than $D$, and $E_{1}\left[V E_{n}\right]$ must fall by strictly less than $\alpha \operatorname{Pr}\left(V_{n}>D\right)$. Thus, a unit rise in $n$ will cause the equityholders' "option value" to fall by an absolute value strictly less than $\frac{1}{2} \alpha$.

To consider the effect of $n$ upon the "efficiency gains" component, note that the derivative of $\frac{1}{2} \alpha(e+n-1)$ with respect to $n$ is $\frac{1}{2} \alpha$, which is unambiguously positive. This positive effect upon the "efficiency gains" component of the equityholders' share must be greater than the absolute value of the negative effect upon the "option value" component. Thus, each unit increase in $n$ must cause $V E_{1}$ to increase.

Proof of Proposition 7. By the same reasoning used in Section 2.2backward induction from round $n$ to round 1 -the equityholders would obtain (4), that is, $V E_{1}=\frac{1}{2} \alpha(e+n-1)+E_{1}\left[V E_{n}\right]$. If $L<V_{n}$, however, then $V E_{n}$ will not equal $V E_{L}$. Consider the reasoning used to derive (3) with respect to the financial distress costs, but substitute $\lambda$ for $\alpha$, round $n$ for round $i$, and liquidation for round $i+1$. One can show that the party making the offer in round $n$ would hold its opponent to its payoff from liquidation and thereby 
obtain the surplus from avoiding liquidation, $\lambda$, plus its own payoff from liquidation. In liquidation, the equityholders would receive $V E_{L}=$ $\max \left(0, V_{n}-\lambda-D\right)$, and the debtholders would receive the complementary share $V D_{L}=L-V E_{L}=V_{n}-\lambda-\max \left(0, V_{n}-\lambda-D\right)=\min \left(V_{n}-\lambda, D\right)$.

Each party would make the offer in round $n$ (and thus capture the surplus $\lambda$ ) with probability $\frac{1}{2}$. In this case, $E_{1}\left[V E_{n}\right]=\frac{1}{2} \lambda+E_{1}\left[V E_{L}\right]$, and substituting this expression in (4) yields

$V E_{1}=\frac{1}{2} \alpha(e+n-1)+\frac{1}{2} \lambda+E_{1}\left[V E_{L}\right]$.

Consider the reasoning used to prove Lemma 1, but applied to $L$ rather than to $V_{n}$. An analogous lemma implies that (A6) equals (16).

Proof of Proposition 8. The loss from liquidation, $\lambda$, affects $V E_{1}$ through both the second and third terms in (16). Note that the derivative of $L-D$ with respect to $\lambda$ is -1 in any state of the world, that is, for any $k$. Therefore, using Lemma A1,

$$
\frac{\partial E_{1}\left[V E_{L}\right]}{\partial \lambda}=-\operatorname{Pr}(L>D)
$$

By (A7), the derivative of the third term, $E_{1}[\max (0, L-D)]$, with respect to $\lambda$, is $-\operatorname{Pr}(L>D)$. The derivative of the second term with respect to $\lambda$, however, equals $\frac{1}{2}$. The positive effect on the second term would be greater than or equal to the absolute value of the negative effect on the third term, because by Lemma $\mathrm{A} 2, \operatorname{Pr}(L>D) \leq \frac{1}{2}$. Therefore, $V E_{\mathrm{I}}$ is nondecreasing in $\lambda$. Moreover, if $\operatorname{Pr}(L>D)<\frac{1}{2}$, then $V E_{1}$ is increasing in $\lambda$. Lemma A2-which states that if $\left(D-V_{1}\right)+\alpha(n-1)+\lambda \geq \theta$, then $\operatorname{Pr}(L>D)<\frac{1}{2}$-completes the proof.

\section{References}

Baird, Douglas G. 1986. "The Uneasy Case for Corporate Reorganizations," 15 Journal of Legal Studies 127-47.

— and Randal C. Picker. 1991. "A Simple Noncooperative Bargaining Model of Corporate Reorganizations," 20 Journal of Legal Studies 311-49.

Bebchuk, Lucian A. 1988. "A New Approach to Corporate Reorganizations," 101 Harvard Law Review 775-804.

1991. "The Effects of Chapter 11 and Debt Renegotiation on Ex Ante Corporate Decisions," Harvard Law School mimeo.

Bergman, Yaacov Z., and Jeffrey L. Callen. 1991. "Opportunistic Behavior in Debt Renegotiations and an Interior Optimal Capital Structure of the Firm without Deadweight Costs," 29 Journal of Financial Economics 137-71.

Berkovitch, Elazar, and Ronen Israel. 1991. "The Bankruptcy Decision and Debt Contract Renegotiation," University of Michigan, School of Business Administration, mimeo.

Broude, Richard F. 1990. Reorganizations Under Chapter II of the Bankruptcy Code. New York: Law Journal Seminars-Press.

Brown, David T. 1989. "Claimholder Incentive Conflicts in Reorganization: The Role of Bankruptcy Law," 2 Review of Financial Studies 109-23. 
Cramton, Peter C. 1984. "Bargaining with Incomplete Information: An Infinite-Horizon Model with Two-Sided Uncertainty," 51 Review of Economic Studies 579-93.

Cutler, David M., and Lawrence H. Summers. 1988. "The Costs of Conflict Resolution and Financial Distress: Evidence from the Texaco-Pennzoil Litigation," 19 Rand Journal of Economics $157-72$.

Eberhart, Allan C., William T. Moore, and Rodney L. Roenfeldt. 1990. "Security Pricing and Deviations from the Absolute Priority Rule in Bankruptcy Proceedings," 45 Journal of Finance 1457-69.

Franks, Julian R., and Walter N. Torous. 1989. "An Empirical Investigation of U.S. Firms in Reorganization," 44 Journal of Finance 747-69.

Fudenberg, Drew, and Jean Tirole. 1983. "Sequential Bargaining with Incomplete Information," 50 Review of Economic Studies 221-47.

Gertner, Robert, and David Scharfstein. 1991. "A Theory of Workouts and the Effects of Reorganization Law," 46 Journal of Finance 1189-222.

Giammarino, Ronald M. 1989. "The Resolution of Financial Distress," 2 Review of Financial Studies 25-47.

Gilson, Stuart C., Kose John, and Larry H. P. Lang. 1990. "Troubled Debt Restructurings: An Empirical Study of Private Reorganization of Firms in Default," 27 Journal of Financial Economics 315-53.

Grossman, Sanford J., and Motty Perry. 1986. "Sequential Bargaining under Asymmetric Information," 39 Journal of Economic Theory 120-54.

Gul, Faruk, and Hugo Sonnenschein. 1988. "On Delay in Bargaining with One-Sided Uncertainty," 56 Econometrica $601-11$.

Hart, Oliver, and John Moore. 1989. "Default and Renegotiation: A Dynamic Model of Debt," Massachusetts Institute of Technology, Department of Economics, Working Paper No. 520.

— and 1 1990. "A Theory of Corporate Financial Structure Based on the Seniority of Claims," Massachusetts Institute of Technology, Department of Economics, Working Paper No. 560 .

Jackson, Thomas H. 1986. The Logic and Limits of Bankruptcy Law. Cambridge, Mass.: Harvard University Press.

Jensen, Michael C., and William H. Meckling. 1976. "Theory of the Firm: Managerial Behavior, Agency Costs and Ownership Structure," 3 Journal of Financial Economics 305-60.

Kaiser, Kevin M. J. 1991. "A Bargaining Model of Chapter 11 Reorganization," Northwestern University, J. L. Kellogg Graduate School of Management, mimeo.

Lang, Larry, and Rene M. Stulz. 1990. "Does Bankruptcy Lead to Inefficient Investment?" New York University and Ohio State University, mimeo.

Myers, Stewart C. 1977. "Determinants of Corporatc Borrowing," 5 Journal of Financial Economics 147-75.

Normandin, Charles P. 1989. "The Changing Nature of Debt and Equity: A Legal Perspective," in R. W. Kopcke and E. S. Rosengren, eds., Are the Distinctions Between Debt and Equity Disappearing? Boston: Federal Reserve Bank of Boston.

Roe, Mark J. 1987. "The Voting Prohibition in Bond Workouts," 97 Yale Law Journal 232-79.

Rubinstcin, Ariel. 1982. "Perfect Equilibrium in a Bargaining Model," 50 Econometrica 97 109.

Trost, J. Ronald. 1979. "Business Reorganizations Under Chapter 11 of the New Bankruptcy Code," 34 Business Lawyer 1309-46.

Webb, David C. 1987. "The Importance of Incomplete Information in Explaining the Existence of Costly Bankruptcy," 54 Economica 279-88.

Weiss, Lawrence A. 1990. "Bankruptcy Resolution: Direct Costs and Violation of Priority of Claims," 27 Journal of Financial Economics 285-314.

White, Michelle J. 1984. "Bankruptcy Liquidation and Reorganization," in D. E. Logue, ed., Handbook of Modern Finance. Boston: Warren, Gorham, and Lanort. 
